\title{
Transmembrane protein PERP is a component of tessellate junctions and of other junctional and non-junctional plasma membrane regions in diverse epithelial and epithelium-derived cells
}

\author{
Werner W. Franke • Hans Heid • Ralf Zimbelmann • \\ Caecilia Kuhn • Stefanie Winter-Simanowski • \\ Yvette Dörflinger • Christine Grund • Steffen Rickelt
}

Received: 13 March 2013 / Accepted: 22 April 2013 / Published online: 21 May 2013

(C) The Author(s) 2013. This article is published with open access at Springerlink.com

\begin{abstract}
Protein PERP (p53 apoptosis effector related to PMP-22) is a small (21.4 kDa) transmembrane polypeptide with an amino acid sequence indicative of a tetraspanin character. It is enriched in the plasma membrane and apparently contributes to cell-cell contacts. Hitherto, it has been reported to be exclusively a component of desmosomes of some stratified epithelia. However, by using a series of newly generated mono- and polyclonal antibodies, we show that protein PERP is not only present in all kinds of stratified epithelia but also occurs in simple, columnar, complex and transitional epithelia, in various types of squamous metaplasia and epithelium-derived tumors, in diverse epithelium-derived cell cultures and in myocardial tissue. Immunofluorescence and immunoelectron microscopy
\end{abstract}

The finanical support by the Deutsche Krebshilfe (grant no. 106976), the German Ministry for Education and Research (BMBF program START-MSC2, grant 01GN0492) and the German-Israeli Foundation for Scientific Research and Development (GIF grant I-1098-43.11/ 2010) for this study is gratefully acknowledged.

W. W. Franke $(\triangle) \cdot$ H. Heid $\cdot$ R. Zimbelmann $\cdot$ C. Kuhn $\cdot$ S. Winter-Simanowski $\cdot$ Y. Dörflinger $\cdot$ C. Grund $\cdot$ S. Rickelt German Cancer Research Center (DKFZ), Im Neuenheimer Feld 280,

69120 Heidelberg, Germany

e-mail: w.franke@dkfz.de

C. Kuhn

Progen Biotechnik, Maassstrasse 30,

69123 Heidelberg, Germany

Present Address:

S. Rickelt

David H. Koch Institute for Integrative Cancer Research,

Massachusetts Institute of Technology (MIT),

Cambridge, MA 02139, USA allow us to localize PERP predominantly in small intradesmosomal locations and in variously sized, junction-like peri- and interdesmosomal regions ("tessellate junctions"), mostly in mosaic or amalgamated combinations with other molecules believed, to date, to be exclusive components of tight and adherens junctions. In the heart, PERP is a major component of the composite junctions of the intercalated disks connecting cardiomyocytes. Finally, protein PERP is a cobblestone-like general component of special plasma membrane regions such as the bile canaliculi of liver and subapical-to-lateral zones of diverse columnar epithelia and upper urothelial cell layers. We discuss possible organizational and architectonic functions of protein PERP and its potential value as an immunohistochemical diagnostic marker.

Keywords Adhering junctions $\cdot$ Desmosomes $\cdot$ Tessellate junctions $\cdot$ PERP $\cdot$ Tetraspanins $\cdot$ Immunocytochemistry

$\begin{array}{ll}\text { Abbreviations } \\ \mathrm{Ab} & \text { Antibody } \\ \mathrm{mAb} & \text { Monoclonal antibody } \\ \mathrm{pAbs} & \text { Polyclonal antibodies from serum } \\ \mathrm{AJ} & \text { Adherens junction } \\ \mathrm{PBS} & \text { Phosphate-buffered saline } \\ \mathrm{PERP} & \mathrm{p} 53 \text { apoptosis effector related to PMP-22 } \\ \mathrm{TJ} & \text { Tight junction }\end{array}$

\section{Introduction}

Among the "classic" cell-cell junctions (Farquhar and Palade 1963; Staehelin 1974; Franke 2009) the maculae 
adhaerentes (desmosomes) appear to be particularly well defined by their specific ultrastructural architecture, their specific anchorage of intermediate-sized filaments and their specific molecular composition (Franke et al. 1981, 1982; Gorbsky and Steinberg 1981; Cowin and Garrod 1983; Mueller and Franke 1983; Cowin et al. 1985b, 1986; for more recent reviews, see Godsel et al. 2004; Holthöfer et al. 2007; Garrod and Chidgey 2008; Delva et al. 2009; Franke 2009). These molecules include one or more representatives of each of the two cadherin-type transmembrane glycoprotein subgroups, the desmogleins (Dsg1-4) and the desmocollins (Dsc1-3), both rooted in a dense protein plaque that lies on the cytoplasmic side and that contain the armadillo protein plakoglobin and at least one representative of another armadillo protein group, the plakophilins (Pkp1-3), together with the large representative of the plakin family of proteins, desmoplakin (see aforementioned review articles). At various times, further constitutive components of desmosomes have been proposed, from desmoyokin to desmocalmin but these have never been confirmed as general desmosomal constituents and have totally disappeared in the more recent literature.

One of the latest additions to the list of constitutive desmosome components has been the rather short (193 amino acids, $21.384 \mathrm{kDa}$ molecular weight) transmembrane polypeptide of the "PMP-22/gas3 family", originally claimed to function as "p53 apoptosis effector related to PMP-22" and thus abbreviated as protein "PERP" (Attardi et al. 2000; Ihrie et al. 2003, 2005, 2006; Ihrie and Attardi 2005; for recent reviews, see Beaudry et al. 2010a, 2010b; Dusek and Attardi 2011). This polypeptide, considered to be a tetraspanin from its amino acid sequence homology to other proteins, has been reported to occur specifically and exclusively in the desmosomes of stratified epithelia (see references cited), in the "composite junctions" of the heart (Marques et al. 2006; see also Christensen et al. 2011) as well as in some pathogenic tissues and some cultured cells derived from stratified epithelia (Marques et al. 2005, 2006; Nguyen et al. 2009).

As we and others have not detected PERP in our enriched or purified desmosomal fractions, mostly from bovine muzzle epidermis (see Skerrow and Matoltsy 1974a, 1974b; Drochmans et al. 1978; Franke et al. 1981, 1982; Gorbsky and Steinberg 1981; Cowin and Garrod 1983; Mueller and Franke 1983; Skerrow and Skerrow 1983; Giudice et al. 1984; Cowin et al. 1985b, 1986; Skerrow 1986; Godsel et al. 2004), we have prepared mono- and polyclonal antibodies (mAbs and pAbs) of high specificity for and avidity to various potential epitope-bearing PERP domains. These antibodies (Abs) have allowed us to detect the PERP molecule as a general and abundant epithelial marker protein in simple, columnar, complex, transitional and stratified epithelia and in the composite junctions of the myocardial intercalated disks, in diverse tumors and in several cell cultures derived from epithelia or carcinomas. Moreover, we have found that protein PERP is not a desmosome-specific component but is an abundant cobblestone-element in peri- and interdesmosomal membrane regions, in particular in the "areae tessellatae", the tessellate junction regions of stratified epithelia in which it forms molecular mosaics with other components, including diverse tight junctions (TJs) and adherens junction (AJ) molecules.

\section{Materials and methods}

\section{Tissues}

Bovine tissue samples were obtained from the regional slaughterhouse (Mannheim, Germany) and murine (rat and mouse) tissues were from animals of the laboratory-animal facilities of the German Cancer Research Center (Heidelberg, Germany; for details, see Franke et al. 2006). In addition, tissue specimens from fetal German landrace pigs and 3year-old boars were provided by the Institute of Farm Animal Genetics (Friedrich-Loeffler-Institute, Mariensee, Germany; see Rickelt et al. 2011a, 2011b). Cryopreserved human tissue samples, including tumor tissues, were obtained from material taken and examined for diagnostic pathology and processed in compliance with the regulations of the Ethics Committees of the Universities of Heidelberg and Marburg (Germany; for details, see Langbein et al. 2003; Franke et al. 2006; Barth et al. 2009; Moll et al. 2009) or were provided by the National Center for Tumor Diseases (NCT, Heidelberg, Germany).

In general, the samples were fixed either with $4 \%$ formaldehyde in phosphate-buffered saline (PBS) and embedded in paraffin or were snap-frozen in isopentane that had been precooled in liquid nitrogen and then stored at $-80^{\circ} \mathrm{C}$ until use. Suitable frozen tissues (e.g., bladder, cornea, esophagus, exocervix, gingiva, heart, intestine, lung, liver, mammary gland, pancreas, skin, snout and tongue) were also used for preparations of sections (ca. $50 \mu \mathrm{m}$ thick) to be analyzed by SDS-polyacrylamide gel electrophoresis (SDS-PAGE) for proteins (see below).

\section{Cell cultures}

Monolayer cell cultures of various human cell lines were examined, including the breast adenocarcinoma-derived line MCF-7, $\mathrm{HaCaT}$ keratinocytes, the colon adenocarcinoma lines $\mathrm{CaCo} 2$ and HT29 and the hepatocellular carcinoma cell lines PLC, HepG2, Hep3b and HuH7. Bovine epithelium-derived cell lines included mammary-gland-derived cells of lines BMGE, $\mathrm{BMGE}+\mathrm{H}, \mathrm{BMGE}+\mathrm{HE}$, and KE-5. For comparison, rat liver hepatocellular carcinoma cells of the line $\mathrm{MH} 1 \mathrm{Cl} 1$ were studied in parallel. The non-epithelial cell lines tested included the human cell lines K562, RPMI 8226, HL-60, SV80, WI-38 and RD, the 
bovine cell line B1 the rat cell line RVFSMC, and the mouse cell lines 3T3 and L929. All cell cultures were kept and used as described (cf. Franke et al. 1979, 1980b; Schmid et al. 1983; Quinlan et al. 1985; Langbein et al. 2002, 2003; Rickelt 2010; Straub et al. 2011; Pieperhoff et al. 2012).

\section{Antibodies and reagents}

Primary $m A b s$ and guinea pig pAbs were generated against the total PERP protein or PERP domains prepared as synthetic polypeptides. Using the human PERP sequence (accession GenBank: EAW47921.1) and the protein model of PERP as determined by transmembrane prediction programs (cf. Attardi et al. 2000), we chose two peptide sequences located on the outside of the cell plasma membrane (PERP-1 and PERP-2) and two further peptide sequences hypothesized to be located on the inside (PERP-3 and PERP-4) for synthesis (PSL Peptide Speciality Laboratories, Heidelberg, Germany): PERP-1, QSSDHGQTSSLWWKC (amino acid positions [aa] 37-51); PERP-2, CQSLMEYAWGR (aa 65-75); PERP-3, CGPQMLVFLR (a a 100-109); PERP-4,: (C)EDDLLGNAKPRYFYTSA (aa 177-193).

The peptides, coupled via cysteins to keyhole limpet hemocyanin, were used for the immunization of animals. In the case of PERP-4 in which a natural cystein within the peptide sequence is missing, an amino acid "(C)-" was synthetically added at the N-terminus. Using these peptides, we immunized guinea pigs and obtained $A b s$ in antisera named as follows: gpPERP-1A, gpPERP-1B, gpPERP-2A,
gpPERP-2B, gpPERP-3A, gpPERP-3B, gpPERP-4A and gpPERP-4B (gp stands for guinea pig). mAbs were generated by immunization of mice with a mixture of all four peptides. Screening of hybridoma cell supernatants was performed by immunofluorescence microscopy with human MCF-7 and HaCaT cells and by SDS-PAGE with cytoskeletal protein preparations from bovine muzzle epidermis, followed by immunoblotting. We selected four clones for the experiments described in this report: PERP-8.2.9, PERP8.2.11, PERP-26.2.22, and PERP-26.3.30.

The murine $\mathrm{mAbs}$ and the guinea pig or rabbit pAbs used for comparison in immunofluorescence microscopy or in immunoblotting analyses of gel-electrophoretically-separated polypeptides against AJ molecules or against diverse cytoskeletal proteins have been described elsewhere (see Barth et al. 2009, 2012; Franke and Rickelt 2011; Rickelt et al. 2009, 2011a). The newly generated Abs were routinely compared with PERP Abs purchased from Abcam (Cambridge, UK) and Sigma-Aldrich (Hamburg, Germany).

Antigen-bound primary Abs were visualized with secondary Abs coupled to Cy3 (Dianova, Hamburg, Germany) or Alexa 488 (MoBiTec, Göttingen, Germany). For immunoblot analysis, horseradish-peroxidase-conjugated secondary Abs were applied (Dianova).

\section{Gel electrophoresis, immunoblotting and fractionations}

Tissue samples and cultured cells were analyzed by SDSPAGE, followed by immunoblotting, as previously

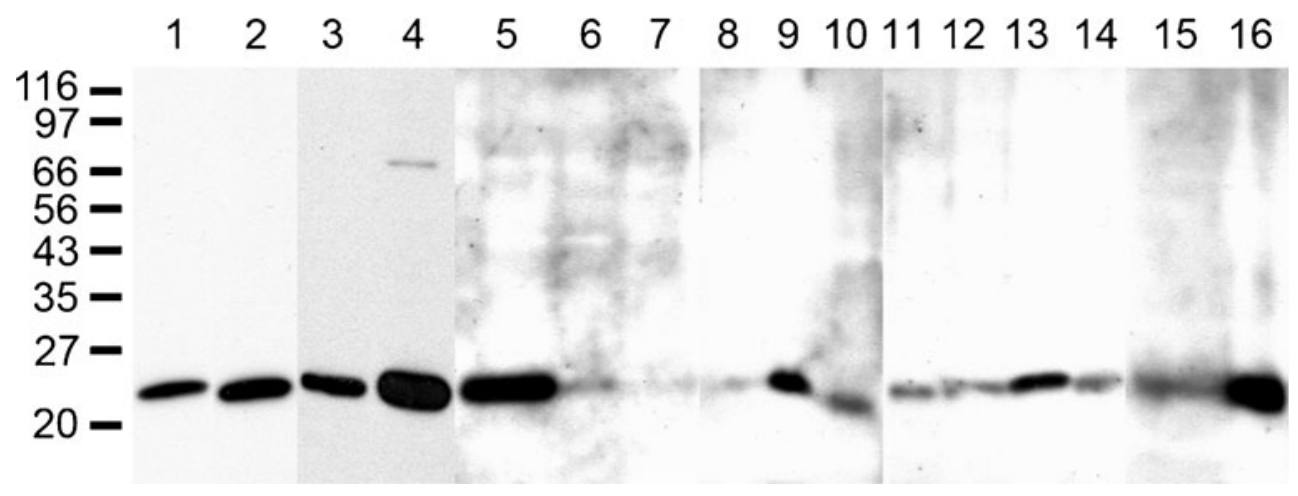

Fig. 1 Immunoblot demonstration of the SDS-polyacrylamide gel electrophoresis (SDS-PAGE)-separated plasma membrane protein PERP (p53 apoptosis effector related to PMP-22) in mammalian epithelial and carcinoma cells and in cardiac tissue by using mouse monoclonal antibodies (mAbs) m8.2.9 (lane 1) or m26.3 (lane 2) with cultured human keratinocytes of line HaCat (lanes 1, 2) or bovine muzzle epithelium (lane 3; reaction of a 1:1 volume mixture of both murine $\mathrm{mAbs}$ ). Lanes $4-16$ show reactions with guinea pig polyclonal antibodies (pAbs) against PERP serum (gpPERP-4A) on SDS-PAGEseparated polypeptides of bovine muzzle (lane 4) or human tongue (lane 5) epithelium, human heart (lane 6) and liver (lane 7) tissue, human hepatic (lane 8) and cholangiocellular carcinoma (lane 9) tissue, bovine liver tissue (lane 10), various human cultured cells of the hepatocellular carcinoma lines Hep3b (lane 11), HuH-7 (lane 12) and PLC (lane 13) and cytoskeletal fractions from cultured cells of the human hepatocellular carcinoma line HepG2 (lane 14) or the human colon carcinoma lines $\mathrm{CaCo} 2$ (lane 15) and HT29 (lane 16). Relative molecular weight values (in $\mathrm{kDa}$ ) of reference polypeptides analyzed in a parallel lane are given left. Note that all these cells and tissues and the cytoskeletal fractions show the specific reaction with the PERP polypeptide with an electrophoretic mobility corresponding to $23 \mathrm{kDa}$. The weak band with an electrophoretic mobility corresponding to an approximate molecular weight of $68 \mathrm{kDa}$ in lane 4 might represent a homo- or heteromeric complex of PERP, which has not been completely separated under these specific solubilization conditions. Exposure times of the specific blots to the film were $10 \mathrm{~min}$ (lanes 1-4) and $15 \mathrm{~min}$ (lanes 5-16) 

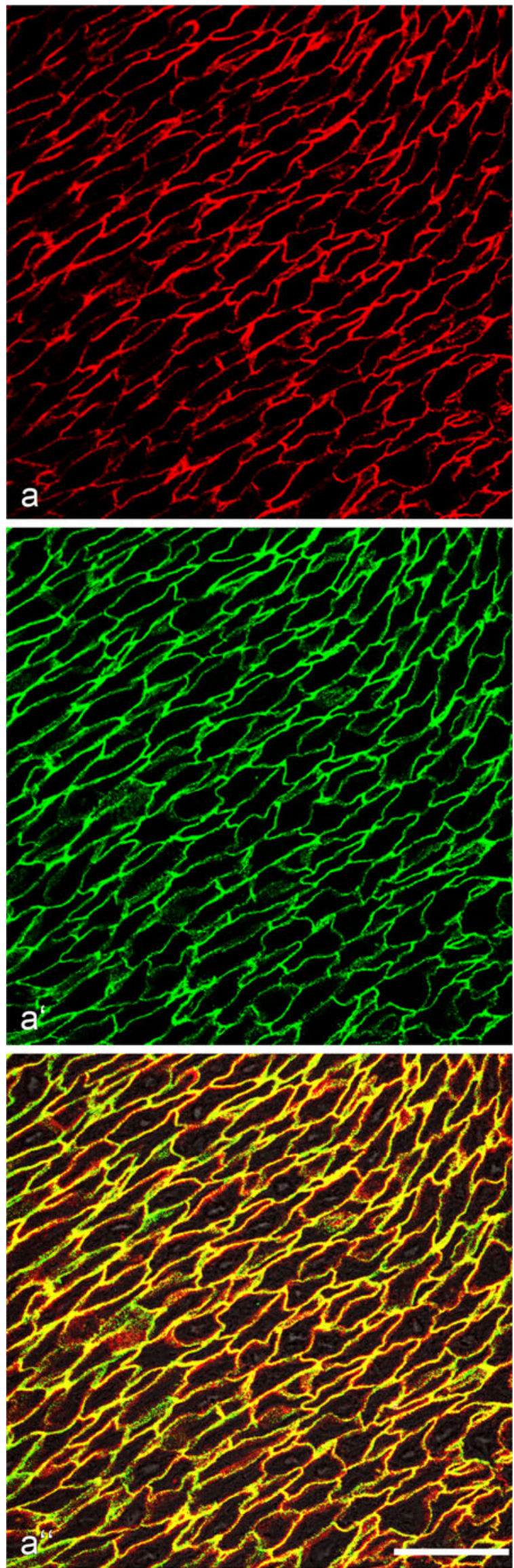

4Fig. 2 Double-label confocal laser-scanning immunofluorescence microscopy of a cryostat section through a lateral portion of bovine tongue mucosa after reaction with murine $\mathrm{mAb} \mathrm{m} 26.3$ (a) against protein PERP and rabbit pAbs to $\beta$-catenin (a'), followed by reaction with the specific secondary Abs. Cryostat section treated with formaldehyde for $8 \mathrm{~min}$, followed by treatment with saponin-containing buffer. a Primary murine Ab against PERP (red). a' Primary rabbit Abs against $\beta$-catenin (green). a" Double-label (merged colors). Note the dominance of the membrane-membrane contact lines (yellow merged color). Bar $50 \mu \mathrm{m}$

described (Rickelt et al. 2011a; Barth et al. 2012; Pieperhoff et al. 2012). Briefly, for preparations of cell lysates, monolayer cell cultures were rinsed twice with PBS and suspended in SDS-sample buffer (125 mM TRIS-HCl, $\mathrm{pH}$ 6.8, 4\% SDS, $20 \%$ glycerol, $20 \mathrm{mM}$ dithiothreitol) containing benzonase (Merck, Darmstadt, Germany) by using a rubber policeman. Tissue lysates were prepared in the same sample buffer and approximately 100 cryostat sections (30-50 $\mu \mathrm{m}$ thick) of the specific tissue regions were collected. After homogenization, the cell or tissue lysates obtained were heated to and kept at ca. $95^{\circ} \mathrm{C}$ for $4-5 \mathrm{~min}$ and centrifuged at $15,000 \mathrm{~g}$ for $10 \mathrm{~min}$. Both the supernatant and the pelleted proteins and glycoproteins were subjected to SDS-PAGE, followed by transfer to polyvinylidene difluoride membranes (ImmobilonP; Millipore, Bedford, MA, USA). For immunoblot analyses, horseradish-peroxidase-conjugated secondary Abs were applied in combination with an enhanced chemiluminescence system (ECL; Fisher Scientific, Schwerte, Germany).

To minimize protein degradation, the fractionations of cell and tissue lysates were performed on ice and with additions of protease inhibitors (Complete Mini Inhibitor Tabs; Roche Diagnostics, Mannheim). Cells were washed twice in PBS, scraped off the cell culture dish surface with a rubber policeman and disrupted with a Dounce homogenizer (B. Braun Biotech, Melsungen, Germany). Cryopreserved tissue samples were sectioned by using a cryotome and approximately 200 sections were usually sampled for homogenization in a Dounce homogenizer. Tissue or cell lysates were centrifuged at $10,000 \mathrm{~g}$ for $10 \mathrm{~min}$ and the pellets were treated with $1 \%$ Triton X-100 in PBS ("low salt buffer"), followed by centrifugation and another extraction of the pellets in $1 \%$ Triton $\mathrm{X}-100,0.5 \mathrm{M} \mathrm{NaCl}$ in PBS ("high salt buffer"). After a final centrifugation step, the residual pellets (referred to as the cytoskeletal or insoluble fraction) were resuspended in SDS sample buffer $(50-100 \mu \mathrm{l})$.

Immunofluorescence microscopy

Methods for immunofluorescence microscopy were essentially as previously described (see Langbein et al. 2002, 2003; Franke et al. 2006; Rickelt et al. 2009, 2011a; Pieperhoff et al. 2012; Rickelt 2012). In routine preparations, the cultured cells grown on poly-(L)-lysine-coated 

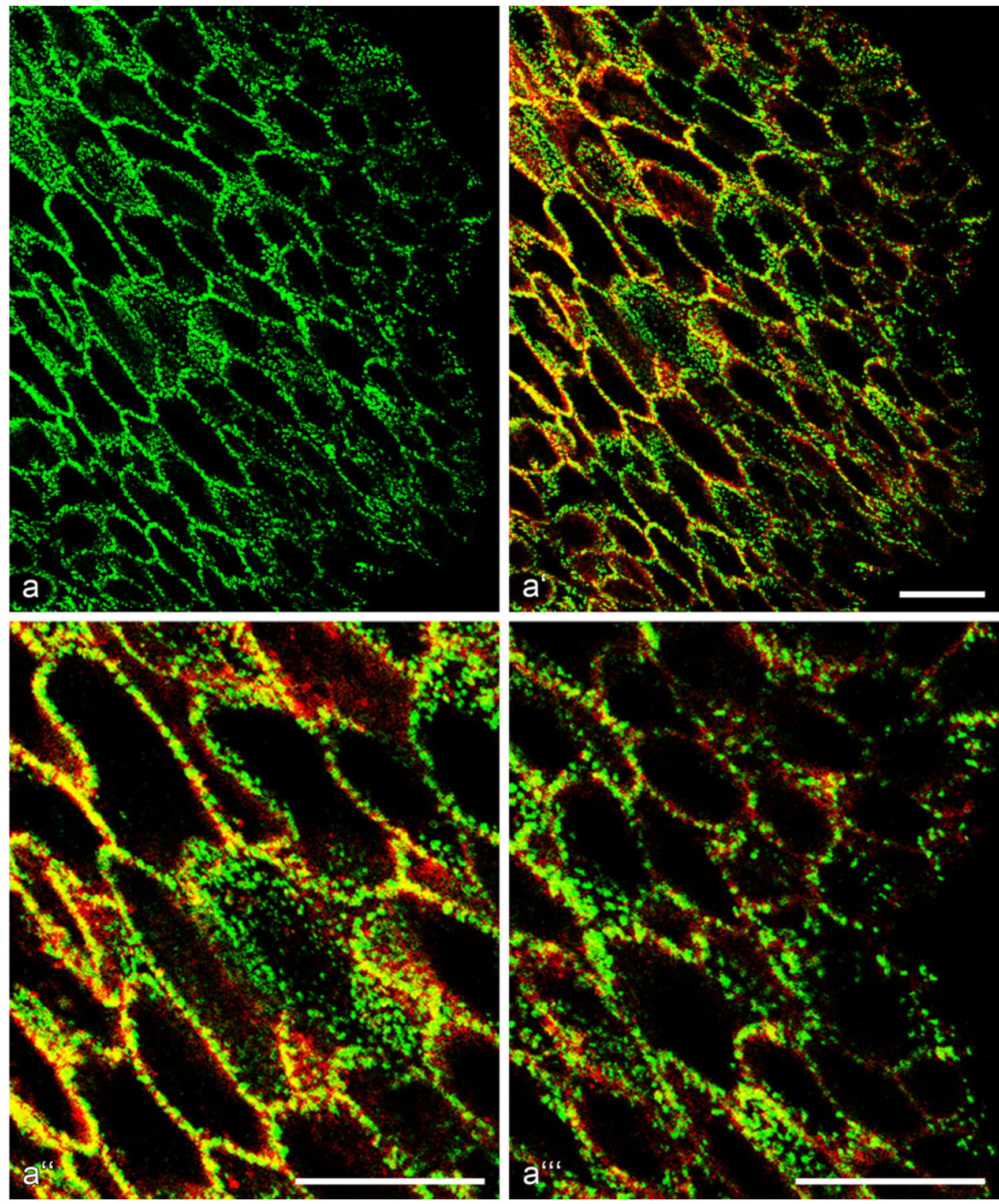

Fig. 3 Double-label confocal laser scanning immunofluorescence micrograph of an oblique grazing section of bovine tongue mucosa (frozen tissue section as in Fig. 2) and guinea pig pAbs against desmoplakin (a, green) or a murine mAb against protein PERP (a', red; mAb 26.3). a Note the desmoplakin reactions, i.e., distinct dot-like desmosomes. a'-a" Merged color reaction with intensely immunostained punctate desmosomes (a-a",

green dots) in direct comparison with the red-stained PERP-positive structures (a'-a"'). a", a" Higher magnifications of a'. Note that, in many places, desmosomal and non-desmosomal structures are clearly distinguishable, whereas in other places, they cannot be individually resolved but appear in the yellow merged color. Note also that in may places tiny yellow or red dots appear at the margins or even within green desmosomes. Bars $20 \mu \mathrm{m}$ 


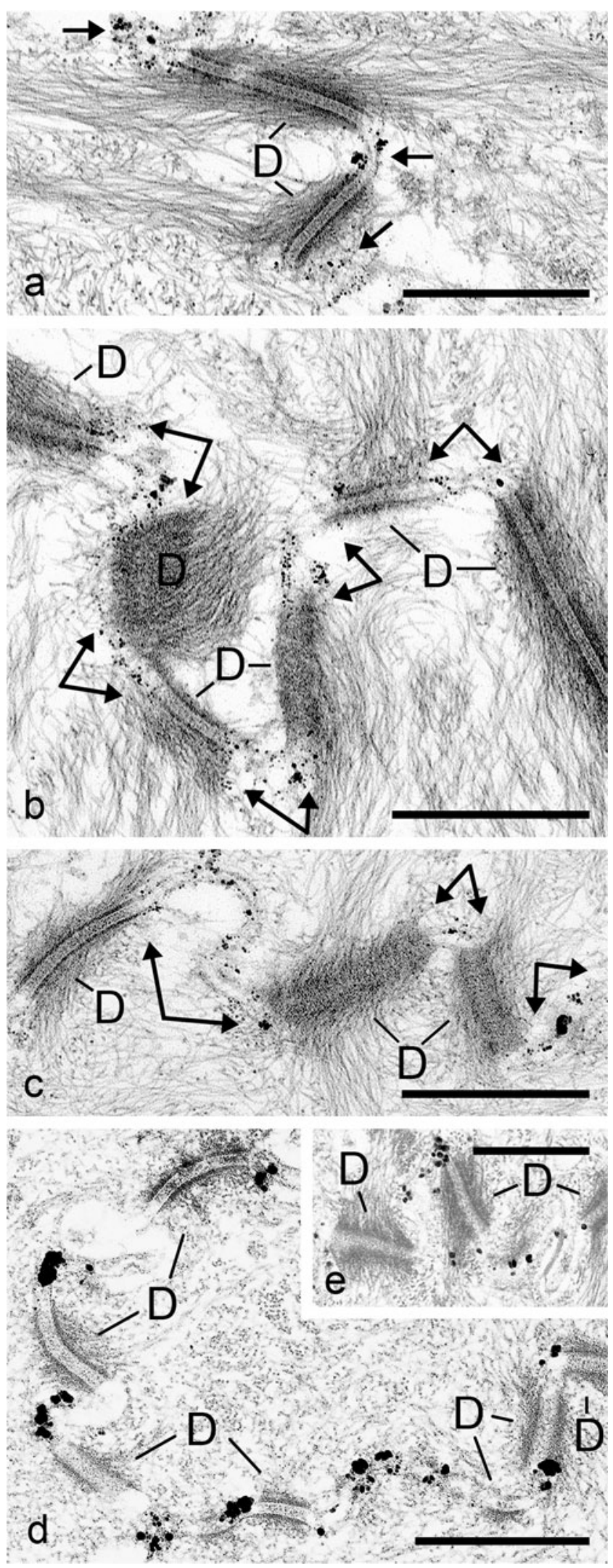

coverslips were briefly rinsed with $\mathrm{PBS}$ and fixed at $-20^{\circ} \mathrm{C}$ in methanol $(5 \mathrm{~min})$ and acetone $(30 \mathrm{~s})$. The frozen tissue
Fig. 4 Immunoelectron microscopy of frozen bovine tongue mucosa epithelium, treated with Abs to protein PERP $(\mathbf{a}-\mathbf{c})$, to occludin $(\mathbf{d})$, or to claudin-4 (e) and reacted with immunogold and a tertiary enhancement silver reaction. Note that the silver-enhanced antigen-gold grains decorating PERP are predominantly located in the regions between the desmosomes $(D)$, i.e., in the interdesmosomal space (arrows in $\mathbf{a}-\mathbf{c}$ ), not infrequently in direct contact with desmosomal margins. In such interdesmosomal regions of stratified epithelia, various proteins typical for tight junctions (TJs) and for adherens junctions (AJs) are also localized (tessellate junctions). Bars $500 \mathrm{~nm}$

sections were mounted on coverslips, air-dried for several hours and fixed for $10 \mathrm{~min}$ in $-20^{\circ} \mathrm{C}$ acetone. The cell or tissue specimens were rehydrated in PBS and pre-incubated with PBS containing $0.2 \%$ Triton $\mathrm{X}-100$ for $5 \mathrm{~min}$ before application of the primary Abs. In parallel, the cells or tissue samples were fixed for 5-7 min in PBS containing 2\% formaldehyde, freshly prepared from paraformaldehyde, and the cells were permeabilized with PBS containing $0.2 \%$ saponin (5 min), followed by exposure to the specific primary Abs in PBS for $1 \mathrm{~h}$, several washes in PBS for 5-10 min each and exposure to the specific secondary Abs for $30 \mathrm{~min}$. After two washes for 5-10 min in PBS, the cell preparations or cryosections were rinsed in distilled water, fixed for $5 \mathrm{~min}$ in ethanol and mounted in Fluoromount G (Southern Biotech; obtained through Biozol Diagnostica, Eching, Germany). Finally, immunofluorescence microscopic images were recorded with an Axiophot II photomicroscope (Carl Zeiss, Jena, Germany), equipped with an AxioCam HR (Carl Zeiss). For confocal laser scanning microscopy, a Zeiss LSM 510 Meta instrument was used.

\section{Immunoelectron microscopy}

The immunoelectron microscopy protocols were essentially as previously described (see Langbein et al. 2002, 2003; Franke et al. 2006; Rickelt et al. 2008; 2011a, 2011b). Cryostat sections of the mammalian tissue samples of the species aforementioned were fixed in PBS containing 2\% formaldehyde for 5-7 min and permeabilized with PBS containing $0.1 \%$ saponin (3-5 min), followed by incubation with primary Abs for at least $2 \mathrm{~h}$. After three washing steps, the samples were incubated with secondary Abs conjugated with 1.4-nm gold particles (Nanogold, Biotrend, Cologne, Germany) for $4 \mathrm{~h}$, followed by silver enhancement for various periods of time (5, 7, or $9 \mathrm{~min})$. Electron micrographs were taken at $80 \mathrm{kV}$, by using an EM 900 (Carl Zeiss).

\section{Results}

Biochemical demonstration of protein PERP in epithelial, carcinoma and myocardiac cells of tissues and cell cultures

Using the novel set of mAbs and pAbs generated as described above, we have identified protein PERP by SDS- 
PAGE and immunoblotting as a polypeptide band with an electrophoretic mobility corresponding to ca. $23 \mathrm{kDa}$, i.e., only slightly slower than expected from the molecular weight calculated from the amino acid sequence (cf. Attardi et al. 2000; Ihrie et al. 2005). Two-dimenstional gel electrophoresis essentially confirmed the isoelectric point value calculated for human PERP protein, i.e., pI 6.68. These analyses showed that PERP occurred not only in all the diverse stratified epithelia examined and in cell culture lines derived therefrom such as the human epidermal keratinocyte line HaCaT (Fig. 1, lanes 1-5) but also in heart tissue, in simple, columnar, complex and transitional epithelia and in cell cultures of lines derived from diverse kinds of
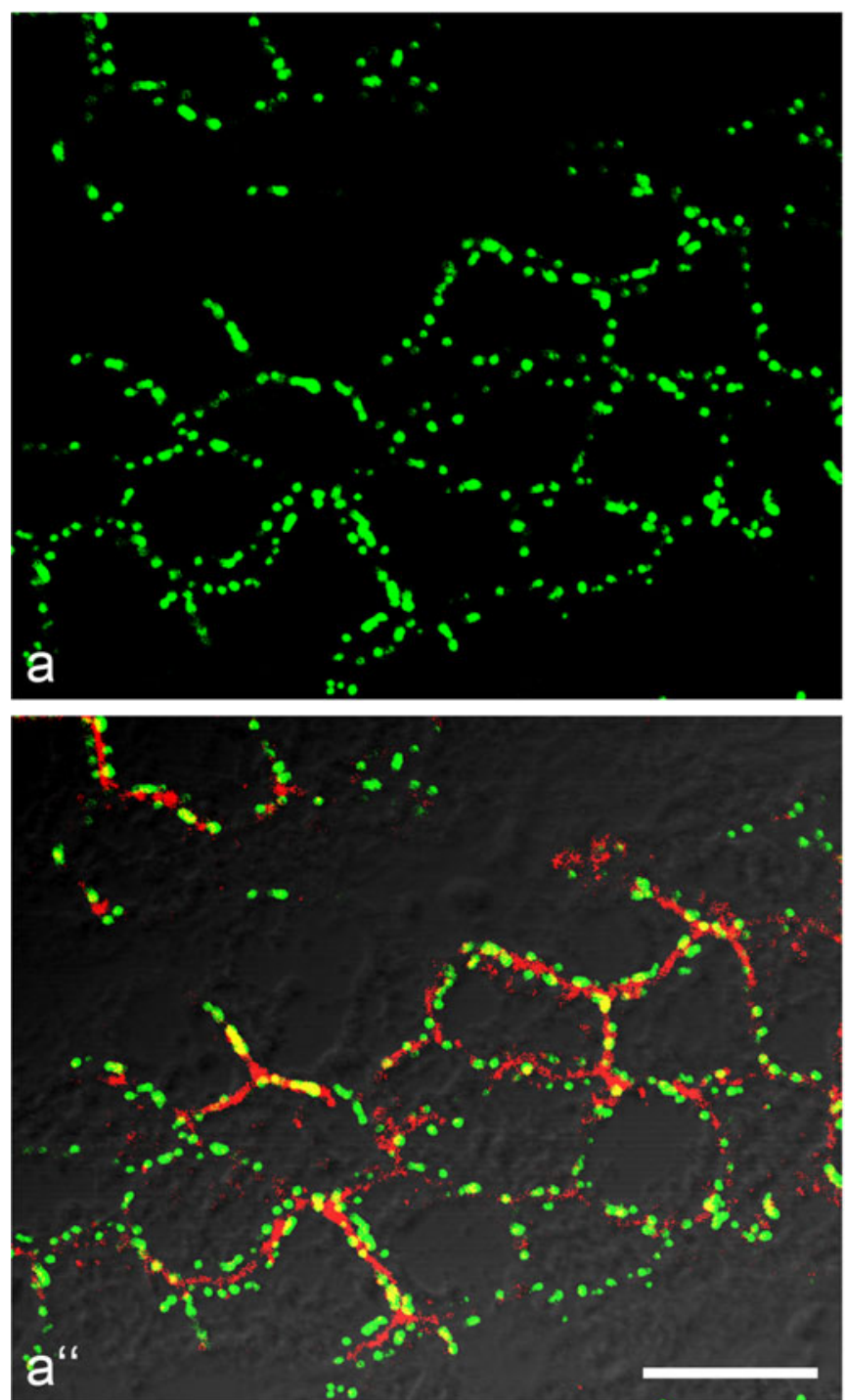

Fig. 5 Confocal laser-scanning double-label immunofluorescence microscopy of cryostat sections through snap-frozen bovine liver after reactions with guinea pig pAbs to desmoplakin (green) and murine $\mathrm{mAbs}(\mathrm{mAb}$ 8.2.9) against protein PERP (red). Note the typical arrays of dot-like desmosomes (green) along the bile canalicular plasma membrane structures of the hepatocytes (a) and the extended PERP- epithelia and epithelium-derived tumors (for examples, see Fig. 1, lanes 6-16). Positive PERP immunoreactions were obtained in human, bovine, porcine and murine (rat and mouse) tissues. By contrast, negative immunoreactions were obtained in natural and culture-grown endothelial cells and in the diverse non-epithelial cell culture lines examined (see Materials and methods).

Immunofluorescence microscopy of stratified epithelia

Extended cell-cell contact lines positively immunostained for protein PERP were seen in all stratified epithelia, including stratified squamous epithelia and in several human tumors
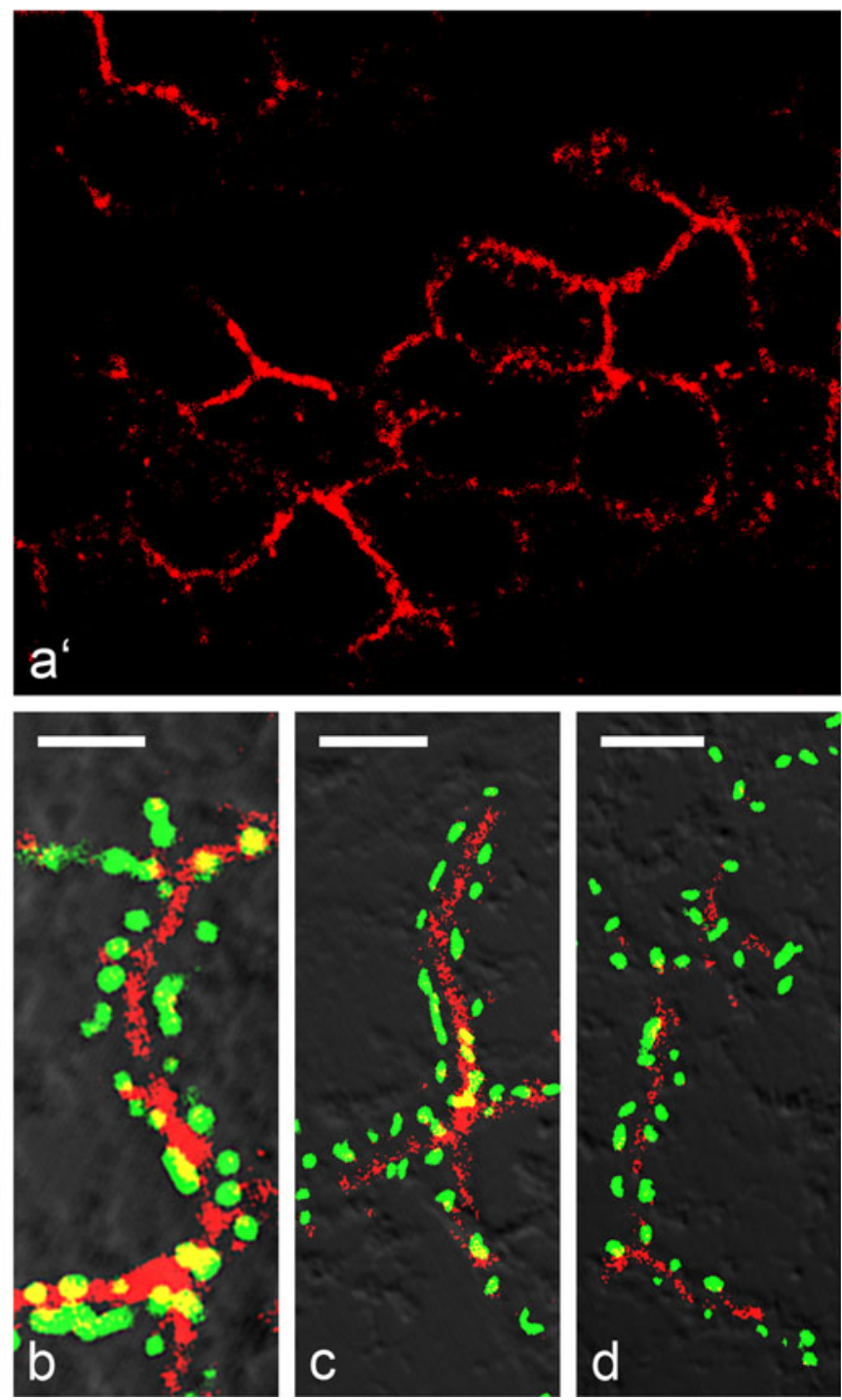

positive reactions (red) near some of these desmosomes and along the canalicular surface membrane (a', a'). Note, in particular, the difference between the distinct dotted (green) desmosomal structures and the continuous $(\mathbf{b}, \mathbf{c})$ or interrupted $(\mathbf{d})$ canalicular plasma membrane reaction of PERP Abs (red). Bars $20 \mu \mathrm{m}$ (a), $5 \mu \mathrm{m}(\mathbf{b}-\mathbf{d})$ 

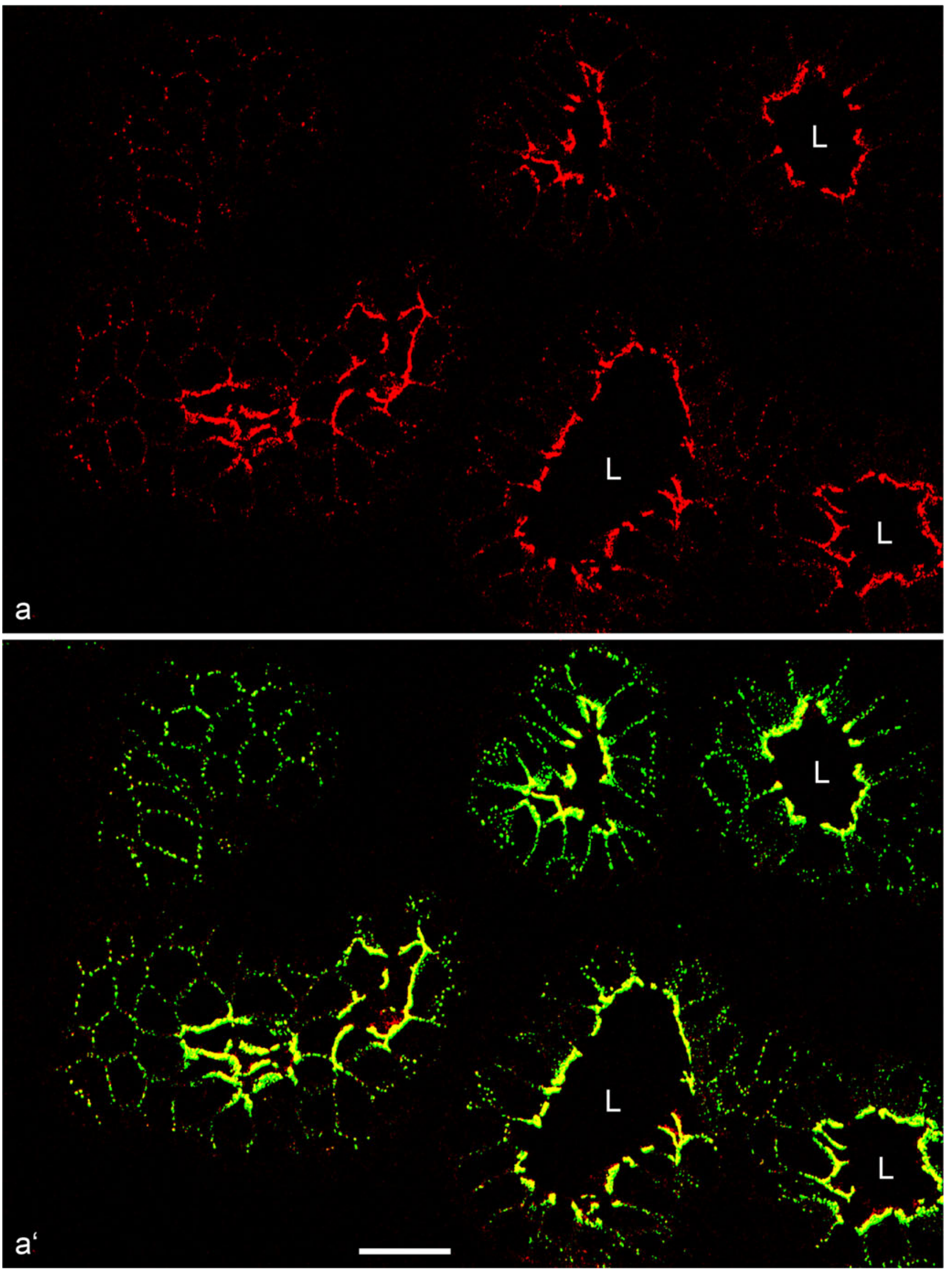
4 Fig. 6 Confocal laser-scanning double-label immunofluorescence microscopy of a cryostat cross-section through snap-frozen bovine intestinal epithelium, after $10 \mathrm{~min}$ treatment with acetone and $5 \mathrm{~min}$ with buffer containing $0.2 \%$ Triton $\mathrm{X}-100$, followed by a reaction with murine mAbs (26.2.22) against protein PERP (a red) and guinea pig pAbs against desmoplakin (a', green; only the hybrid double-color picture is shown here in which the coincidence of both colors appears in yellow). Note the enrichment of both desmosomes and PERPcontaining structures in the subapical cell-cell junction-containing region (red in a, yellow in a') but also that some of the desmosomes at the basolateral sides appear as yellow dots indicative of the close vicinity of the two proteins, whereas many strictly green and a few strictly red punctate structures can also be recognized ( $L$ lumen). Bar $20 \mu \mathrm{m}$

derived from such tissues. Figure 2 presents a double-labeled example, indicating (but not proving) the far-reaching colocalization of PERP with $\beta$-catenin on a cryostat section through bovine tongue mucosa. These PERP-positive strata also included those of the cornea of the eye and the limbus, confirming the report of Ding et al. (2008). Whereas in some stratified squamous epithelia, all strata were positive for PERP, in other tissues some positive layers were seen as well as others being almost negative. Such epithelia with PERP-positive and negative-appearing cell layers included various regions of the epidermis (not shown).

Double-label immunofluorescence microscopic comparisons of PERP-positive structures in all the stratified epithelia examined (cf. Materials and methods; Fig. 3 bovine tongue mucosa) with desmosomes, as detected with Abs to desmoplakin, plakophilins, plakoglobin and desmogleins, also revealed distinctly different PERP localizations. A marked, generally variable proportion of the desmosomes remained totally unstained but PERP protein was present in all interdesmosomal regions and only infrequently near or within the confinements of some desmosomes (Fig. 3).

Differences of PERP-positive structures in the various stratified epithelia in comparison with the corresponding metaplasias, squamous cell carcinomas and metastatic tumors will be dealt with in a subsequent publication.

\section{Immunoelectron microscopy of protein PERP}

When cryostat sections through the same stratified tissue as presented in Figs. 1, 2, 3, i.e., bovine and human tongue, were prepared for immunoelectron microscopy, protein PERP was abundantly noted in interdesmosomal regions, i.e., in plasma membrane structures mostly in close contact (12-18 nm membrane-membrane distance) with the membrane of the neighboring cell (Fig. 4a-c). Mostly, this membrane-membrane distance was smaller in the interdesmosomal regions than in the desmosomes. Even the smallest of these interdesmosomal membrane intercepts revealed immunogold-silver enhancement grains, not infrequently in close association with the desmosomal margins or even protruding into the apparent desmosomal structure.
Essentially similar results were obtained for tongue mucosa of all five species examined and for gingiva, esophagus and epidermis (not shown). These observations of close-spaced cell-cell-connecting junction-like interdesmosomal structures, which also regularly contained TJ hallmark proteins such as occludin (Fig. 4d) and claudin-1 and/or claudin-4 (see Fig. 4e) and $\mathrm{AJ}$ proteins such as catenins, plakoglobin, protein p120 and protein ZO-1, led us to the concept of and the definition of variably sized, cell-cell contact regions representing special junctions in their own right, our so-called tessellate junctions, formed by mosaic-like molecular arrays of PERP in combination with small groups of various TJ and AJ proteins. As repeatedly noted by previous authors, typical AJs are rarely seen in such interdesmosomal regions (see Kaiser et al. 1993; Horiguchi et al. 1994; Haftek et al. 1996). Gap junction structures were often noted within these tessellate junction regions.

Immunofluorescence microscopy of PERP in simple, columnar and complex epithelia

Using our highly sensitive new Abs, we not only discovered PERP protein in diverse types of simple and columnar epithelia by SDS-PAGE (cf. Fig. 1) but also by immunofluorescence and immunoelectron microscopy. Figure 5a-a", for example, presents a double-label immunolocalization comparison of protein PERP and desmoplakin in the most studied internal organ, the liver. Here, hepatocyte-hepatocyte contact sites of the plasma membrane regions surrounding the bile canaliculi are recognized as serial arrays of desmosomes, whereas most (in some types of preparations, apparently all) reactive PERP protein is located in the "free" bile canalicular membranes, i.e., junction-free hepatocyte plasma membrane regions (for details, see Fig. 5b-d). These desmosomes seem to contain only small amounts of PERP protein, if any and the PERP here represents a frequent component of the canalicular membrane continuum.

A quite different kind of PERP-containing structure has been noted in simple columnar epithelia with apicalbasolateral polarity, such as the intestinal epithelium, for which two (surprisingly differing) examples, based on two different kinds of fixations, are presented in Figs. 6, 7. In Fig. 6, an apparently high density of PERP and obviously good PERPepitope accessibility are characteristic of the subapical zone near (or overlapping with) the zonula adhaerens and the relatively densely packed desmosomes in this zone, as indicated by the yellow merged color (Fig. 6a'). In addition, desmosomeassociated and interdesmosomal small punctate PERP immunostaining sites are seen along the lateral membranes, some exhibiting a yellow merged color, whereas other PERPpositive dots are located in-between desmosomes. By contrast, in the cryostat sections fixed in formaldehyde and treated with a mild detergent (Fig. 7), a marked and thick-appearing PERP enrichment is seen along the lateral membranes. 

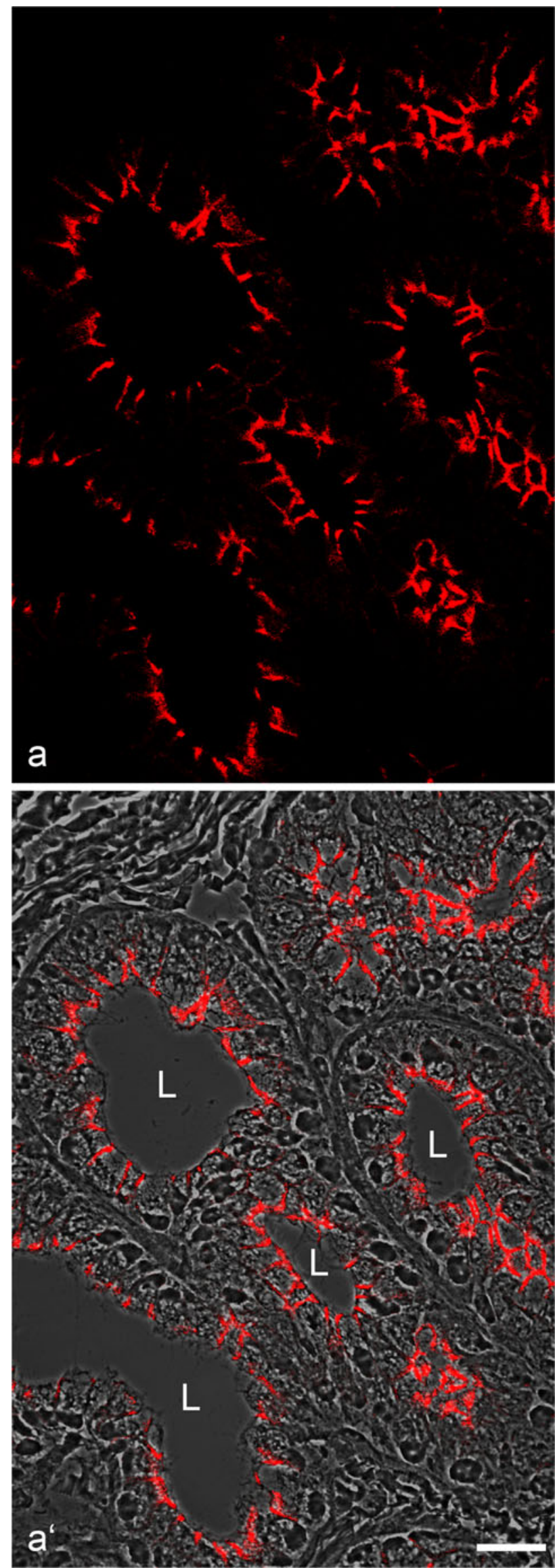

Fig. 7 Fixation-dependent appearance of protein PERP in bovine intestinal epithelium as seen after $8 \mathrm{~min}$ of fixation with buffer containing $2 \%$ formaldehyde, followed by a short washing step and a 4-min treatment with buffer containing $0.1 \%$ saponin and then reaction with $\mathrm{mAb}$ (26.3.30) to PERP and secondary antibodies (a' is a shown on a phase contrast background). Note that prominent PERP staining is seen along the lateral membranes and that most of the staining appears in continuous stripes, whereas individual dots and subapical zonulalike rings are rarely present ( $L$ lumen). Bar $20 \mu \mathrm{m}$

Essentially similar observations (also with remarkable differences between the different fixation protocols) have been made in other polar epithelia, including the bile duct epithelium. Generally, in such epithelia, one sees an intense enrichment of PERP protein at the level of the zonula adhaerens and along the lateral membranes (Fig. 8a-c" provides examples of porcine and human lung) in which distinct PERPpositive dots are rarely discerned.

We have also seen PERP immunostaining in plasma membrane structures in all cells of the complex epithelia examined, including the two kinds of cells of the "pseudostratified" epithelium of the lactating mammary gland in the tissue and in cell cultures (not shown). Here, the cuboidal-to-columnar luminal cells, which mostly contact the basal lamina only via cell protrusions or processes, are as PERP-positive as the entire basal, elongated, and branched myoepithelial cells (Franke et al. 1980a; Schmid et al. 1983; Daniel and Silberstein 1987; Taylor-Papadimitriou and Lane 1987; see also the recent report of Dusek et al. 2012).

Immunofluorescence microscopy of PERP in transitional epithelium

A special local enrichment of PERP protein is seen in the transitional epithelium of the bladder, namely the urothelium in which this protein is obviously enriched in the uppermost cell layers (Fig. 9). In the large umbrella cells of the adluminal cell layer (for ultrastructural details, see Hicks et al. 1974), obliquely horizontal (Fig. 9) and longitudinal (Fig. 10) sections allow the resolution and distinction of a single (umbrella) cell layer with a zonula adhaerens containing $\beta$-catenin (Figs. 9, 10) from a subjacent layer with $\alpha$ catenin, proteins p120, p0071 and plakoglobin, together with E-cadherin (not shown). $\beta$-Catenin-containing circumferential junctions are also seen in all the more basal urothelial cell layers. We have only distinctly seen an extended and intensely PERP-positive lateral plasma membrane region characterized by numerous clustered PERP-dots below the $\beta$-catenin-positive zonula adhaerens (Fig. 10a-c).

Protein PERP: a component of the myocardiac composite junctions

Finally, protein PERP is also a consistent and major molecule of the composite junctions (areae compositae) of the 

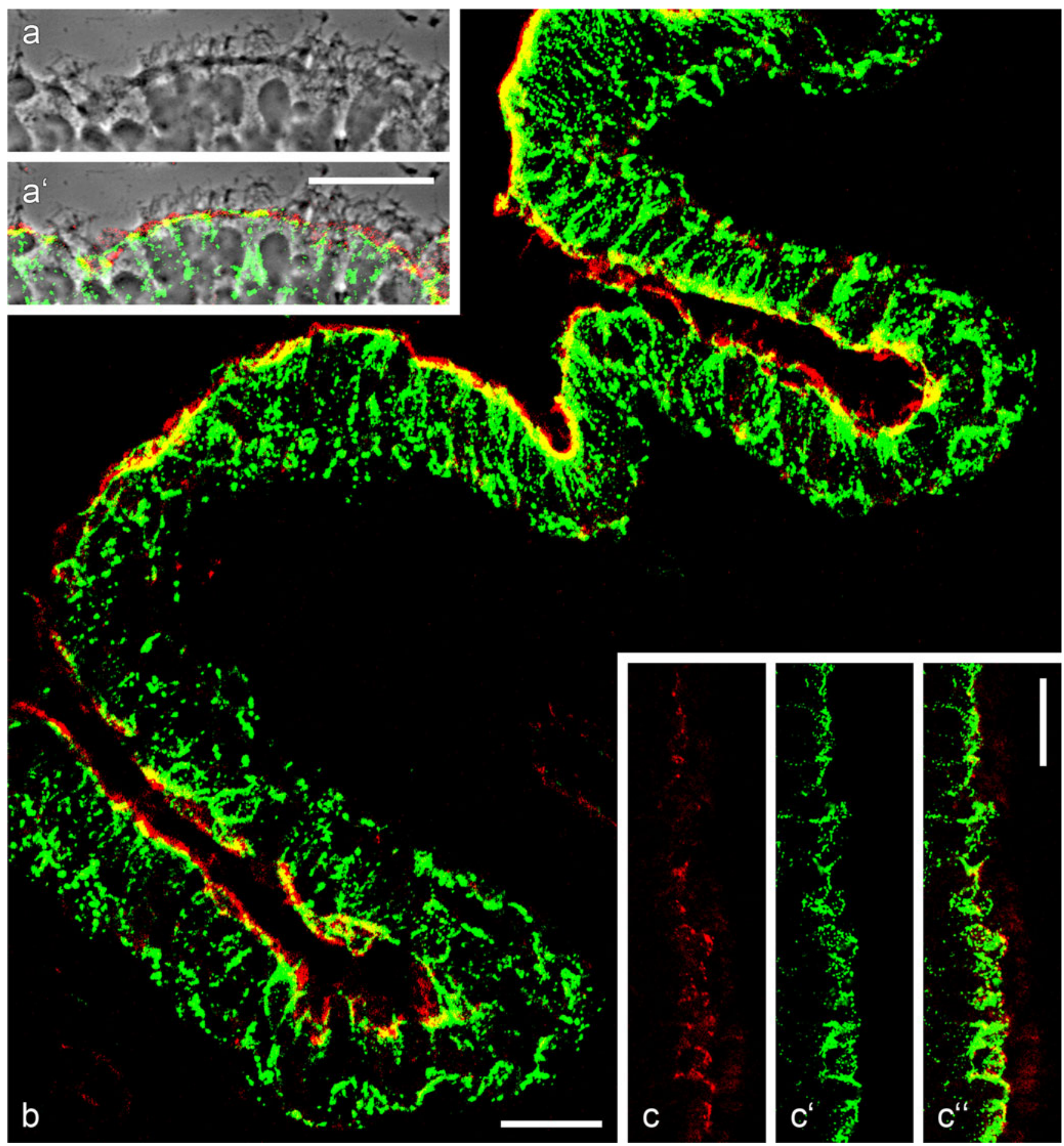

Fig. 8 Confocal laser-scanning double-label immunofluorescence microscopy of a cryostat section through snap-frozen porcine $(\mathbf{a}, \mathbf{b})$ or human (c-c") lung tissue, followed by treatment with mAbs (a mAb 26.2.22; b mAb 26.3.30; c-c" mAb 8.2.9) against protein PERP (red) and guinea pig pAbs against desmoplakin (green). Note the striking enrichment of PERP-containing structures in a subapical zonula-like region of the pulmonary epithelium, which, in some places, is clearly resolved from the adjacent desmosomes, thus appearing as a redstained subapical ring-band (many locations in a', b). While the

bronchial cilia (top in a, a', shown on a phase contrast background) are negative, most of the more basolaterally located cell-cell contact regions show thin but distinct, zonula-like, red-stained PERP-enriched structures (see also human bronchial epithelium in $\mathbf{c}-\mathbf{c}$ "). In contrast, desmosomes without any PERP reaction are enriched along the lateral cell-cell contact regions (green). Tissue section samples were solubilized and fixed by a 10-min incubation in acetone and a 5-min treatment with buffer containing $0.2 \%$ Triton X-100. Bars $20 \mu \mathrm{m}$ 

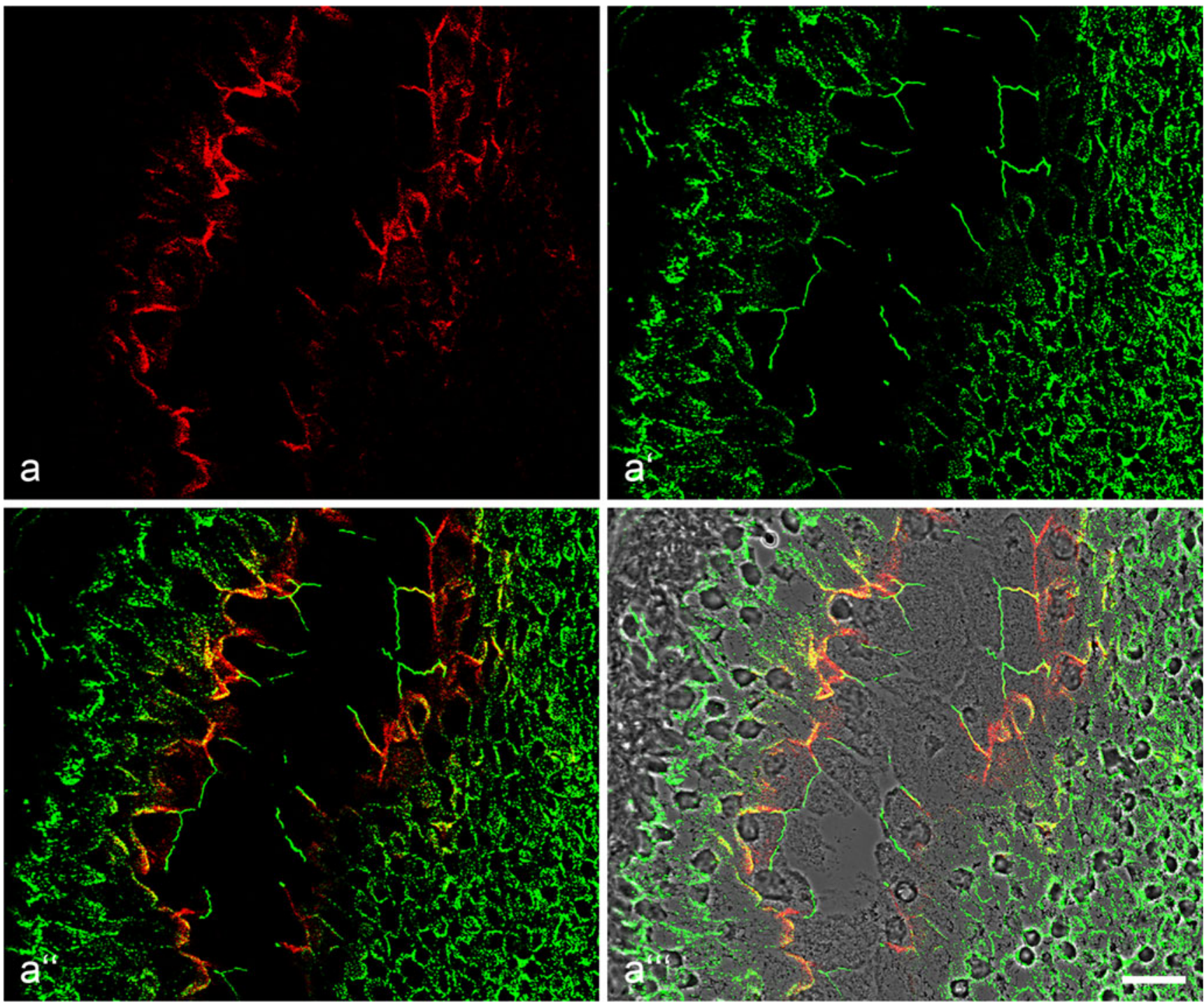

Fig. 9 Confocal laser-scanning double-label immunofluorescence microscopy of an obliquely horizontal cryostat section through snapfrozen bovine bladder epithelium (urothelium) after reaction with murine PERP mAb 26.2.22 (a, red) and rabbit $\beta$-catenin pAbs (a', green). The double-label fluorescence micrograph is presented as a", while the double-label picture on a phase contrast background is seen in a". Protein PERP is only seen at the basolateral region of the uppermost cell layer, the so-called umbrella cells, whereas the $\beta$ -

intercalated disks connecting cardiomyocytes in a pole-topole fashion; these junctions have been characterized as a hybrid amalgamated fusion structure of desmosomal and AJ components (cf. Borrmann 2000; Borrmann et al. 2000; Franke et al. 2006, 2007). Our immunofluorescence and immunoelectron microscopic results (see Fig. 11a-c) show an almost complete colocalization of protein PERP with desmosomal (e.g., Fig. 11a-a") and AJ hallmark proteins (Fig. 11b, c), thus confirming an earlier report by Marques et al. (2006) and the definition of the hybrid composite junction. catenin-rich zonulae adhaerentes represent the most apical junction structure in the form of a typical zonula adhaerens (note the long green structures). The more basal layers of much smaller cells are characterized by the presence of only $\beta$-catenin-rich (green) cell-cell contacts. Such immunolocalization allows the distinction of an outer, apparently PERP-free, junctional region, a slightly more basal region containing protein PERP and the more basally located cells lacking PERP. Bar $20 \mu \mathrm{m}$

\section{Discussion}

Hitherto, the transmembrane protein PERP has been regarded as a constitutive molecule of the desmosomes of various stratified epithelia and consequently, the possible functions of PERP have been discussed with respect to such epithelia, notably epidermal keratinocytes (e.g., Ihrie et al. 2005, 2006; for reviews, see Beaudry et al. 2010a, 2010b; Dusek and Attardi 2011). These reports and discussions have included the development of PERP-/- mice, which suffer perinatal death accompanied by severe epidermal 

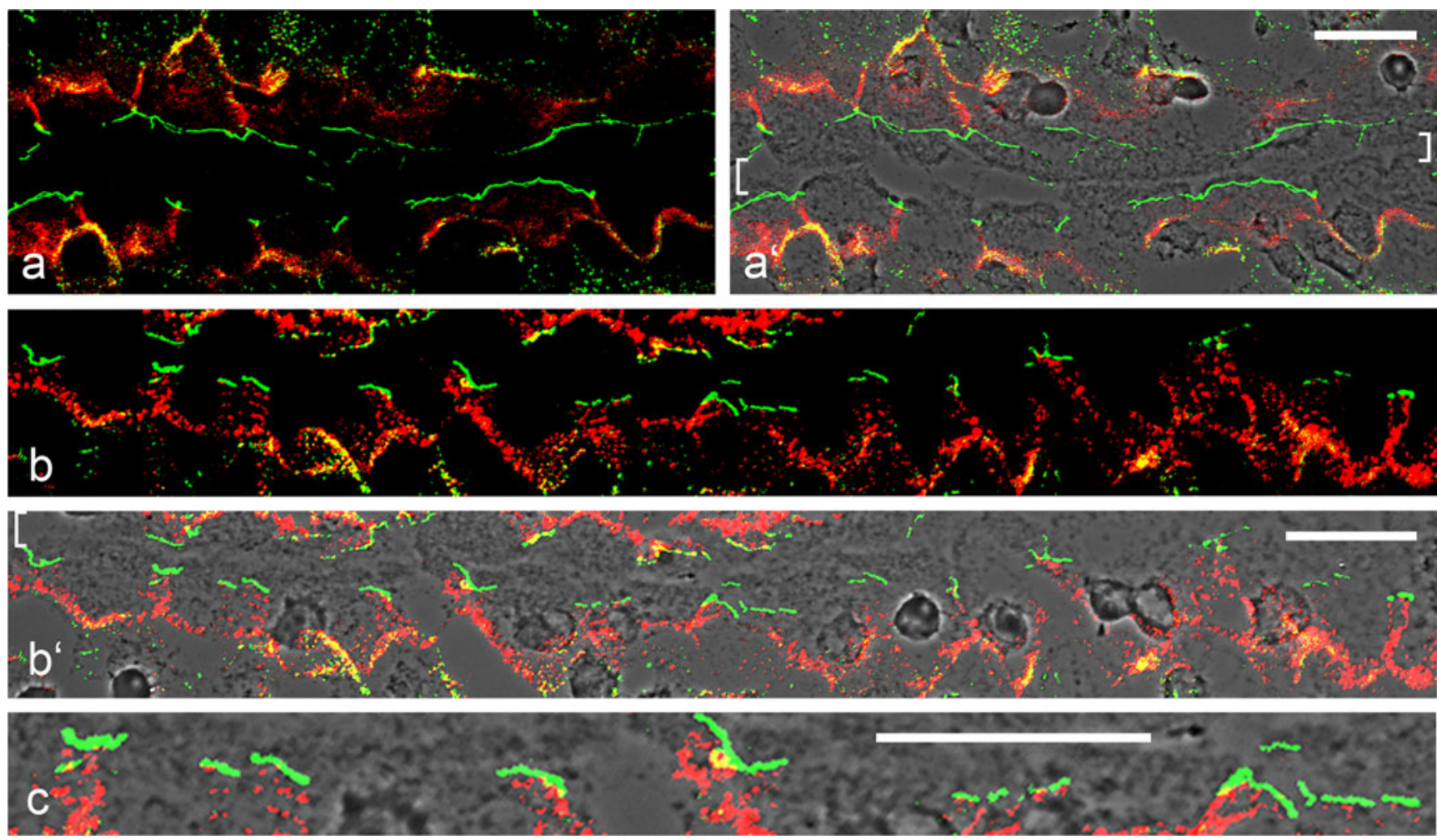

Fig. 10 Higher magnification of a vertical section through the most apical region of umbrella cells in a preparation similar to that in Fig. 9 but stained with mAbs to PERP (red) and rabbit pAbs to $\beta$-catenin (green). The urothelium is collapsed so that two surface regions face each other (bracket in a' residual luminal space). a Double-label immunofluorescence result only. a' Same area on a phase contrast background. b The double-label appearance of this extended region

blisterings. In general, these observations and functionrelevant conclusions have emphasized that the loss of PERP protein results in decreased cell-cell adhesion combined with skin blistering, documented by many gaps between the epidermal cells, in particular in the basal cell layer. PERP is also thought to contribute to the "cleaning" of PERP-containing stratified epithelia by the induction and promotion of apoptotic programs and to suppress tumor formation and spreading (see the aforementioned reviews) and PERP dysregulation might result in the pathogenesis of certain genetic diseases of the skin, scalp, hair and nails (Beaudry et al. 2009). In addition, Attardi and colleagues have reported that PERP influences papilloma development in mice (Marques et al. 2005). Obviously, the possible PERP functions and the developmental and pathogenic roles of PERP will have to be reconsidered on the basis of the present report.

Our study has demonstrated that protein PERP is by no means restricted to certain stratified epithelia but also occurs as a frequent component in the plasma membranes of all simple, columnar, complex and transitional epithelia studied, including hepatocytes, bile and pancreatic duct epithelium, formed by umbrella cells is again shown on a phase-contrast background in b'. $\mathbf{c}$ Higher magnification of $\mathbf{b}$ allows the demonstration of the individual cell surface reactions in detail: the most apical reaction is that of $\beta$-catenin (green) in the zonulae adhaerentes and is clearly distinguishable from the densely aggregated punctate PERP pattern (red) along the lateral membranes of this cell layer. Bars $20 \mu \mathrm{m}$

all parts of the gastrointestinal tract, the bladder and other urogenital epithelia, the lung epithelia and a variety of further glandular epithelia, the mammary gland included. Not surprisingly, considering the epithelial derivation of cardiomyocytes, PERP is also a major component of the special bipolar junctions that, in the postnatal heart, connect cardiomyocytes in the so-called "intercalated disk", i.e., an amalgamation of both desmosomal and AJ proteins (composite junctions; Borrmann 2000; Borrmann et al. 2000; Franke et al. 2006; see also Goossens et al. 2007; Li et al. 2012; van Hengel et al. 2013). Thus, we now have to examine the more general hypothesis that protein PERP is a major plasma membrane protein in all kinds of epithelial cells, perhaps also including the epithelioid cells in tissues without a lumen, such as the thymic reticulum and its spheroidally arranged Hassall bodies or the "horn pearls" in certain tumors (for references, see Langbein et al. 2003) and the dendritic follicular epithelial reticulum of the lymph nodes (for reviews, see Wacker 1994; Moll et al. 2009). Protein PERP might also occur in the plasma membranes of meningothelial cells of the arachnoidea and meningiomas for which 

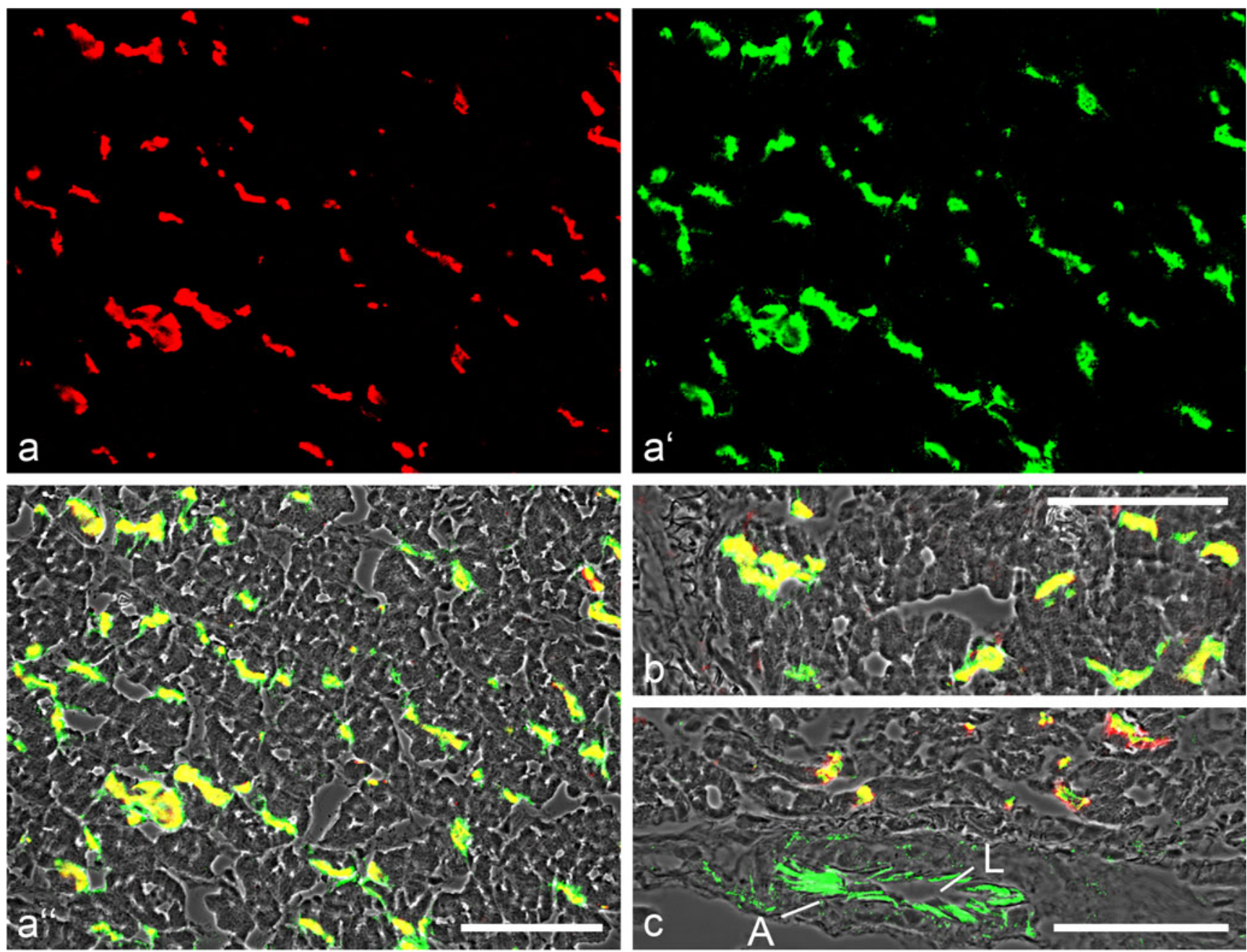

Fig. 11 Confocal laser-scanning double-label immunofluorescence microscopy of cryostat sections through frozen bovine heart tissue, prepared with the formaldehyde-saponin procedure (see Fig. 7 and Material and methods) and immunostained with guinea pig pAbs to PERP protein (a', green) in comparison with murine mAbs (red) to desmoplakin (a, a") or $\beta$-catenin (b), whereas in c, immunostaining with rabbit pAbs against $\beta$-catenin (green) is compared with

desmosomes have also been demonstrated (e.g., Kartenbeck et al. 1984; Schwechheimer et al. 1984; Parrish et al. 1986; Akat et al. 2008).

Such a general study will also have to include epithelium-derived cell layers growing in culture. Here, we have examined protein PERP with biochemical and immunolocalization methods in a variety of cell types derived from epithelial tissues or epithelium-derived tumors and have found PERP in the plasma membranes of several monolayer cultures (see Materials and methods and Results). On the other hand, we have also obtained a series of unexpected results, as PERP has been identified in various epithelium- or carcinoma-derived cell lines tested with SDSPAGE but not in plasma membranes by immunolocalization microscopy in which we have seen here positive reactions immunostaining with mouse PERP mAbs (red). Note, in all micrographs, the near-complete co-immunostaining (yellow) of protein PERP with both desmoplakin and $\beta$-catenin in the composite junctions of the intercalated disks. Note also, in $\mathbf{c}$, the exclusive $\beta$-catenin immunostaining of the zonulae adhaerentes (green) in the arteriole $(A)$ in comparison with the yellow merged immunostaining of the composite junctions ( $L$ lumen). Bars $50 \mu \mathrm{m}$

only in cytoplasmic juxtanuclear aggregates of PERP-positive structures.

In view of the results described in this report, we are currently also examining the potential value of protein PERP as a general epithelial cell-type marker in tumor diagnosis, i.e., for adenomas and carcinomas and, in particular, their metastases and in heterogeneous tumors such as those often classified as "carcinosarcomas". Here, our preliminary data suggest that PERP will provide a third general epithelial tumor cell-type marker in routine diagnostics, in addition to specific keratins and desmosomal proteins.

The results of this study have also shown that protein PERP is not a general and constant component of all desmosomes. Although PERP can be detected in close contact with desmosomes or even in small intradesmosomal 
"islands" (an association, for example, with desmoglein Dsg2 has been occasionally found by immunoprecipitations with HaCaT cell lysates), the major portion of PERP in stratified simple epithelia appears to be located in interdesmosomal membrane areas where it often contributes (together with some $\mathrm{TJ}$ and $\mathrm{AJ}$ proteins) to the formation and maintenance of variously sized, junction-like mosaic junctions also characterized by a close membrane-membrane association (12-18 $\mathrm{nm}$ distance), markedly narrower than in the neighboring desmosomes. Consequently, we have grouped these variously sized and apparently also variously patterned mosaic structures under the name of tessellate junctions. In most stratified epithelia, these tessellate junctions are prominent simply by them representing the largest proportion of the cell-cell contact area, exceeding even the desmosomal contribution. This novel and complex but extended and important category will be the subject of a forthcoming article.

Another important and perhaps the most surprising, result of this report is our finding that protein PERP is not an exclusively cell-cell junction-associated protein. Its extended, relatively homogenous distribution in the bile canalicular plasma membrane and in special regions of polar simple epithelia and in urothelial cells (see Fig. 10) demonstrate that PERP can form and stabilize cobblestone-like arrays in special cell surface regions not involved in cell-cell contact structures. Moreover, in a separate study, we have followed the exo- and endocytic processes of PERP-containing membrane areas in a similar mode as in our previous studies with desmosomal proteins (e.g., Duden and Franke 1988; Demlehner et al. 1995; Cowin et al. 1985a; Kartenbeck et al. 1982).

With regard to the concept of protein PERP as a frequent, possibly general, component of plasma membranes of epithelial cells, the reports of the Liverpool group of Paraon (e.g., Paraon et al. 2006; Davies et al. 2009, 2011) that PERP occurs in an especially aggressive form of non-epithelial tumor, the uveal melanoma, are unexpected and "disturbing", as a developmental biological connection to epithelial tissues is not obvious. On the other hand, the plasma membranes of certain melanomas have recently also surprisingly been demonstrated to contain a desmosomal cadherin, namely desmoglein 2 (Dsg2), out of a structural desmosomal context, in an unusual state dispersed over the surface membrane (Rickelt et al. 2008). Hence, the surface membranes of melanomas might be a particularly challenging object for research into the roles of cell contact molecules.

Acknowledgments We thank our colleagues of the Monoclonal Antibody Facility (German Cancer Research Center) for their help in the generation of PERP monoclonal antibodies.

Open Access This article is distributed under the terms of the Creative Commons Attribution License, which permits any use, distribution and reproduction in any medium, provided the original author(s) and the source are credited.

\section{References}

Akat K, Bleck CKE, Lee Y-MA, Haselmann-Weiss U, Kartenbeck J (2008) Characterization of a novel type of adherens junction in meningiomas and the derived cell line HBL-52. Cell Tissue Res 331:401-412

Attardi LD, Reczek EE, Cosmas C, Demicco EG, McCurrach ME, Lowe SW, Jacks T (2000) PERP, an apoptosis-associated target of p53, is a novel member of the PMP-22/gas3 family. Genes Dev 14:704-718

Barth M, Schumacher H, Kuhn C, Akhyari P, Lichtenberg A, Franke WW (2009) Cordial connections: molecular ensembles and structures of adhering junctions connecting interstitial cells of cardiac valves in situ and in cell culture. Cell Tissue Res 337:63-77

Barth M, Rickelt S, Noffz E, Winter-Simanowski S, Niemann H, Akhyari P, Lichtenberg A, Franke WW (2012) The adhering junctions of valvular interstitial cells: molecular composition in fetal and adult hearts and the comings and goings of plakophilin-2 in situ, in cell culture and upon re-association with scaffolds. Cell Tissue Res 348:295-307

Beaudry VG, Pathak N, Koster MI, Attardi LD (2009) Differential PERP regulation by TP63 mutants provides insight into AEC pathogenesis. Am J Med Genet 149A:1952-1957

Beaudry VG, Ihrie RA, Jacobs SB, Nguyen B, Pathak N, Park E, Attardi LD (2010a) Loss of the desmosomal component PERP impairs wound healing in vivo. Dermatol Res Pract 2010:759731

Beaudry VG, Jiang D, Dusek RL, Park EJ, Knezevich S, Ridd K, Vogel H, Bastian BC, Attardi LD (2010b) Loss of the p53/p63 regulated desmosomal protein Perp promotes tumorigenesis. PLoS Genet 6:e1001168

Borrmann CM (2000) Molekulare Charakterisierung der AdhärensZellverbindungen des Herzens: Identifizierung einer neuen Art, der Area composita. [Molecular characterization of the adherenstype cell junctions in the heart: Identification of a novel kind, the area composita.] Ph.D. Thesis, Faculty of Biology, University of Heidelberg, Germany

Borrmann CM, Mertens C, Schmidt A, Langbein L, Kuhn C, Franke WW (2000) Molecular diversity of plaques of epithelial-adhering junctions. Ann NY Acad Sci 915:144-150

Christensen AH, Benn M, Tybjærg-Hansen A, Haunso S, Svendsen JH (2011) Screening of three novel candidate genes in arrhythmogenic right ventricular cardiomyopathy. Genet Test Mol Biomarkers 15:267-271

Cowin P, Garrod DR (1983) Antibodies to epithelial desmosomes show wide tissue and species cross-reactivity. Nature 302:148-150

Cowin P, Franke WW, Grund C, Kapprell H-P, Kartenbeck J (1985a) The desmosome-intermediate filament complex. In: Edelman GM, Thiery J-P (eds) The cell in contact. Wiley, New York, pp 427-460

Cowin P, Kapprell H-P, Franke WW (1985b) The complement of desmosomal plaque proteins in different cell types. J Cell Biol 101:1442-1454

Cowin P, Kapprell H-P, Franke WW, Tamkun J, Hynes RO (1986) Plakoglobin: a protein common to different kinds of intercellular adhering junctions. Cell 46:1063-1073

Daniel CW, Silberstein GB (1987) Postnatal development of the rodent mammary gland. In: Neville MC, Daniel CW (eds) The mammary gland. Development, Regulation, and Function. Plenum Press, New York, pp 3-36

Davies L, Gray D, Spiller D, White MRH, Damato B, Grierson I, Paraoan L (2009) P53 apoptosis mediator PERP: localization, function and caspase activation in uveal melanoma. J Cell Mol Med 13:1995-2007

Davies L, Spiller D, White MRH, Grierson I, Paraoan L (2011) PERP expression stabilizes active p53 via modulation of p53-MDM2 interaction in uveal melanoma cells. Cell Death Dis 2:e136 
Delva E, Tucker DK, Kowalczyk AP (2009) The desmosome. Cold Spring Harb Perspect Biol 1:a002543

Demlehner MP, Schäfer S, Grund C, Franke WW (1995) Continual assembly of half-desmosomal structures in the absence of cell contacts and their frustrated endocytosis: a coordinated Sisyphus cycle. J Cell Biol 131:745-760

Ding Z, Dong J, Liu J, Deng SX (2008) Preferential gene expression in the limbus of the vervet monkey. Mol Vis 14:2031-2041

Drochmans P, Freudenstein C, Wanson J-C, Laurent L, Keenan TW, Stadler J, Leloup R, Franke WW (1978) Structure and biochemical composition of desmosomes and tonofilaments isolated from calf muzzle epidermis. J Cell Biol 79:427-443

Duden R, Franke WW (1988) Organization of desmosomal plaque proteins in cells growing at low calcium concentrations. J Cell Biol 107:1049-1063

Dusek RL, Attardi LD (2011) Desmosomes: new perpetrators in tumour suppression. Nat Rev 11:317-323

Dusek RL, Bascom JL, Vogel H, Baron S, Borowsky AD, Bissell MJ, Attardi LD (2012) Deficiency of the p53/p63 target Perp alters mammary gland homeostasis and promotes cancer. Breast Cancer Res 14:R65

Farquhar MG, Palade GE (1963) Junctional complexes in various epithelia. J Cell Biol 17:375-412

Franke WW (2009) Discovering the molecular components of intercellular junctions - a historical view. Cold Spring Harb Perspect Biol 1:a003061

Franke WW, Rickelt S (2011) Mesenchymal-epithelial transitions: spontaneous and cumulative syntheses of epithelial marker molecules and their assemblies to novel cell junctions connecting human hematopoietic tumor cells to carcinomatoid tissue structures. Int J Cancer 129:2588-2599

Franke WW, Schmid E, Winter S, Osborn M, Weber K (1979) Widespread occurrence of intermediate-sized filaments of the vimentin-type in cultured cells from diverse vertebrates. Exp Cell Res 123:25-46

Franke WW, Schmid E, Freudenstein C, Appelhans B, Osborn M, Weber K, Keenan TW (1980a) Intermediate-sized filaments of the prekeratin type in myoepithelial cells. J Cell Biol 84:633-654

Franke WW, Schmid E, Vandekerckhove J, Weber K (1980b) A permanently proliferating rat vascular smooth muscle cell with maintained expression of smooth muscle characteristics, including actin of the vascular smooth muscle type. J Cell Biol 87:594-600

Franke WW, Schiller DL, Moll R, Winter S, Schmid E, Engelbrecht I, Denk H, Krepler R, Platzer B (1981) Diversity of cytokeratins. Differentiation-specific expression of cytokeratin polypeptides in epithelial cells and tissues. J Mol Biol 153:933-959

Franke WW, Schmid E, Schiller DL, Winter S, Jarasch E-D, Moll R, Denk H, Jackson B, Illmensee K (1982) Differentiation-related patterns of expression of proteins of intermediate-sized filaments in tissues and cultured cells. Cold Spring Harbor Symp Quant Biol 46:431-453

Franke WW, Borrmann CM, Grund C, Pieperhoff S (2006) The area composita of adhering junctions connecting heart muscle cells of vertebrates. I. Molecular definition in intercalated disks of cardiomyocytes by immunoelectron microscopy of desmosomal proteins. Eur J Cell Biol 85:69-82

Franke WW, Schumacher H, Borrmann CM, Grund C, WinterSimanowski S, Schlechter T, Pieperhoff S, Hofmann I (2007) The area composita of adhering junctions connecting heart muscle cells of vertebrates. III. Assembly and disintegration of intercalated disks in rat cardiomyocytes growing in culture. Eur J Cell Biol 86:127-142

Garrod D, Chidgey M (2008) Desmosome structure, composition and function. Biochim Biophys Acta 1778:572-587

Giudice GJ, Cohen SM, Patel N, Steinberg MS (1984) Immunological comparison of desmosomal components from several bovine tissues. J Cell Biochem 26:35-45
Godsel LM, Getsios S, Huen AC, Green KJ (2004) The molecular composition and function of desmosomes. In: Behrens J, Nelson WJ (eds) Cell adhesion, vol 165. Handbook of experimental pharmacology. Springer, Berlin, pp 137-193

Goossens S, Janssens B, Bonné S, De Rycke R, Braet F, van Hengel J, van Roy F (2007) A unique and specific interaction between $\alpha$ T-catenin and plakophilin-2 in the area composita, the mixed-type junctional structure of cardiac intercalated discs. J Cell Sci 120:2126-2136

Gorbsky G, Steinberg MS (1981) Isolation of the intercellular glycoproteins of desmosomes. J Cell Biol 90:243-248

Haftek M, Hansen MU, Kaiser HW, Kreysel HW, Schmitt D (1996) Interkeratinoyte adherens junctions: immunocytochemical visualization of cell-cell junctional structures, distinct from desmosomes, in human epidermis. J Invest Dermatol 106:498-504

Hicks RM, Ketterer B, Warren RC (1974) The ultrastructure and chemistry of the luminal plasma membrane of the mammalian urinary bladder: a structure with low permeability to water and ions. Phil Trans R Soc Lond Biol 268:23-38

Holthöfer B, Windoffer R, Troyanovsky S, Leube RE (2007) Structure and function of desmosomes. Int Rev Cytol 264:65-163

Horiguchi Y, Furukawa F, Fujita M, Imamura S (1994) Ultrastructural localization of E-cadherin cell adhesion molecule on the cytoplasmic membrane of keratinocytes in vivo and in vitro. J Histochem Cytochem 42:1333-1340

Ihrie RA, Attardi LD (2005) A new Perp in the lineup: linking p63 and desmosomal adhesion. Cell Cycle 4:873-876

Ihrie RA, Reczek E, Horner JS, Khachatrian L, Sage J, Jacks T, Attardi LD (2003) Perp is a mediator of p53-dependent apoptosis in diverse cell types. Curr Biol 13:1985-1990

Ihrie RA, Marques MR, Nguyen BT, Horner JS, Papazoglu C, Bronson RT, Mills AA, Attardi LD (2005) Perp is a p63-regulated gene essential for epithelial integrity. Cell 120:843-856

Ihrie RA, Bronson RT, Attardi LD (2006) Adult mice lacking the p53/ p63 target gene Perp are not predisposed to spontaneous tumorigenesis but display features of ectodermal dysplasia syndromes. Cell Death Differ 13:1614-1618

Kaiser HW, Ness W, Jungblut I, Briggaman RA, Kreysel HW, O’Keefe E (1993) Adherens junctions: demonstration in human epidermis. J Invest Dermatol 100:180-185

Kartenbeck J, Schmid E, Franke WW, Geiger B (1982) Different modes of internalization of proteins associated with adhaerens junctions and desmosomes: experimental separation of lateral contacts induces endocytosis of desmosomal plaque material. EMBO J 1:725-732

Kartenbeck J, Schwechheimer K, Moll R, Franke WW (1984) Attachment of vimentin filaments to desmosomal plaques in human meningiomal cells and arachnoidal tissue. J Cell Biol 98:1072-1081

Langbein L, Grund C, Kuhn C, Praetzel S, Kartenbeck J, Brandner JM, Moll I, Franke WW (2002) Tight junctions and compositionally related junctional structures in mammalian stratified epithelia and cell cultures derived therefrom. Eur J Cell Biol 81:419-435

Langbein L, Pape UF, Grund C, Kuhn C, Praetzel S, Moll I, Moll R, Franke WW (2003) Tight junction-related structures in the absence of a lumen: occludin, claudins and tight junction plaque proteins in densely packed cell formations of stratified epithelia and squamous cell carcinomas. Eur J Cell Biol 82:385-400

Li J, Goossens S, van Hengel J, Gao E, Cheng L, Tyberghein K, Shang X, De Rycke R, van Roy F, Radice GL (2012) Loss of $\alpha$ T-catenin alters the hybrid adhering junctions in the heart and leads to dilated cardiomyopathy and ventricular arrhythmia following acute ischemia. J Cell Sci 125:1-10

Marques MR, Horner JS, Ihrie RA, Bronson RT, Attardi LD (2005) Mice lacking the p53/p63 target gene Perp are resistant to papilloma development. Cancer Res 65:6551-6556 
Marques MR, Ihrie RA, Horner JS, Attardi LD (2006) The requirement of Perp in postnatal viability and epithelial integrity reflects an intrinsic role in stratified epithelia. J Invest Dermatol 126:69-73

Moll R, Sievers E, Haemmerling B, Schmidt A, Barth M, Kuhn C, Grund C, Hofmann I, Franke WW (2009) Endothelial and virgultar cell formations in the mammalian lymph node sinus: endothelial differentiation morphotypes characterized by a special kind of junction (complexus adhaerens). Cell Tissue Res 335:109-141

Mueller H, Franke WW (1983) Biochemical and immunological characterization of desmoplakins I and II, the major polypeptides of the desmosomal plaque. J Mol Biol 163:647-671

Nguyen B, Dusek RL, Beaudry VG, Marinkovich MP, Attardi LD (2009) Loss of the desmosomal protein Perp enhances the phenotypic effects of pemphigus vulgaris autoantibodies. J Invest Dermatol 129:1710-1718

Paraoan L, Gray D, Hiscott P, Ebrahimi B, Damato B, Grierson I (2006) Expression of p53-induced apoptosis effector PERP in primary uveal melanomas: downregulation is associated with aggressive type. Exp Eye Res 83:911-919

Parrish EP, Garrod DR, Mattey DL, Hand L, Steart P, Weller RO (1986) Mouse antisera specific for desmosomal adhesion molecules of suprabasal skin cells, meninges, and meningioma. Proc Natl Acad Sci USA 83:2657-2661

Pieperhoff S, Rickelt S, Heid H, Claycomb WC, Zimbelmann R, Kuhn C, Winter-Simanowski S, Frey N, Franke WW (2012) The plaque protein myozap identified as a novel major component of adhering junctions in endothelia of the blood and the lymph vascular systems. J Cell Mol Med 16:1709-1719

Quinlan RA, Schiller DL, Hatzfeld M, Achtstätter T, Moll R, Jorcano JL, Magin TM, Franke WW (1985) Patterns of expression and organization of cytokeratin intermediate filaments. Ann NY Acad Sci 455:282-306

Rickelt S (2010) The molecular and cell biological characterization of cell-cell junctions in mesenchymally derived cells and tissues. Faculty of Biology. University of Heidelberg, Germany

Rickelt S (2012) Plakophilin-2: a cell-cell adhesion plaque molecule of selective and fundamental importance in cardiac functions and tumor cell growth. Cell Tissue Res 348:281-294

Rickelt S, Franke WW, Doerflinger Y, Goerdt S, Brandner JM, Peitsch WK (2008) Subtypes of melanocytes and melanoma cells distinguished by their intercellular contacts: heterotypic adherens junctions, adhesive associations, and dispersed desmoglein 2 glycoproteins. Cell Tissue Res 334:401-422

Rickelt S, Winter-Simanowski S, Noffz E, Kuhn C, Franke WW (2009) Upregulation of plakophilin-2 and its acquisition to adherens junctions identifies a novel molecular ensemble of cell-cell-attachment characteristic for transformed mesenchymal cells. Int J Cancer 125:2036-2048

Rickelt S, Kuhn C, Winter-Simanowski S, Zimbelmann R, Frey N, Franke WW (2011a) Protein myozap - a late addition to the molecular ensembles of various kinds of adherens junctions. Cell Tissue Res 346:347-359

Rickelt S, Moll I, Franke WW (2011b) Intercellular adhering junctions with an asymmetric molecular composition: desmosomes connecting Merkel cells and keratinocytes. Cell Tissue Res 346:65-77

Schmid E, Franke WW, Grund C, Schiller DL, Kolb H, Paweletz N (1983) An epithelial cell line with elongated myoid morphology derived from bovine mammary gland. Exp Cell Res 146:309-328

Schwechheimer K, Kartenbeck J, Moll R, Franke WW (1984) Vimentin filament-desmosome cytoskeleton of diverse types of human meningiomas. A distinctive diagnostic feature. Lab Invest 51:584-591

Skerrow CJ (1986) Desmosomal proteins. In: Bereiter-Hahn J, Matoltsy AG, Richard KS (eds) Biology of the integument 2. Vertebrates. Springer, Berlin, pp 762-787

Skerrow CJ, Matoltsy AG (1974a) Isolation of epidermal desmosomes. J Cell Biol 63:515-523

Skerrow CJ, Matoltsy AG (1974b) Chemical characterization of epidermal desmosomes. J Cell Biol 63:524-530

Skerrow D, Skerrow CJ (1983) Tonofilament differentiation in human epidermis, isolation and polypeptide chain composition of keratinocyte subpopulations. Exp Cell Res 143:27-35

Staehelin LA (1974) Structure and function of intercellular junctions. Int Rev Cytol 39:191-283

Straub BK, Rickelt S, Zimbelmann R, Grund C, Kuhn C, Iken M, Ott M, Schirmacher P, Franke WW (2011) E-N-cadherin heterodimers define novel adherens junctions connecting endoderm-derived cells. J Cell Biol 195:873-887

Taylor-Papadimitriou J, Lane EB (1987) Keratin expression in the mammary gland. In: Neville MC, Daniel CW (eds) The mammary gland. Development, Regulation, and Function. Plenum Press, New York, pp 181-215

van Hengel J, Calore M, Bauce B, Dazzo E, Mazzotti E, De Bortoli M, Lorenzon A, Li Mura IEA, Beffagna G, Rigato I, Vleeschouwers M, Tyberghein K, Hulpiau P, van Hamme E, Zaglia T, Corrado D, Basso C, Thiene G, Daliento L, Nava A, van Roy F, Rampazzo A (2013) Mutations in the area compsita protein $\alpha \mathrm{T}$-catenin are associated with arrhythmogenic right ventricular cardiomyopathy. Eur Heart J 34:201-210

Wacker HH (1994) Sinuswandzellen. Immunakzessorische Zellen des Lymphknotensinus [Sinus lining cells. Immune accessory cells of lymph node sinuses]. Veröffentlichungen aus der Pathologie, Bd. 143. Fischer, Stuttgart 